\title{
The Indication of Integrated Circuit Card (IC Card) in the U.S. with Regard to Nursing and Healthcare two Systems
}

Bingh Tang*

New York College of Traditional Chinese Medicine, Mineola, USA

Submission: March 18, 2018; Published: August 09, 2018

*Corresponding author: Bingh tang, New York College of Traditional Chinese Medicine, Mineola, NY, USA, Email: Prof.Bing@gmail.com

Abstract

This paper will first discuss the IC card and network technology utilized by the Taiwan's 1 National Health Insurance System. Then it will cover the application of this technology in the U.S. Nursing care, as well, Healthcare systems as the comparison.

Overview of the smart card and network technology; privacy and security requirements are mandatory methods. Benefits of using IC cards can be illustrated with Taiwan's excellent result. While disadvantages of using IC cards (mainly, because of privacy concerns.). What are the roadblocks to implement this technology in the U S needs our attention. We should also pay attention to hospitals and providers toward the direction of smart card technology.

Keywords: IC card; Network technology; Nursing Healthcare systems; Taiwan; Single-payer system

\section{Mini Review}

\section{Methodology quality analysis}

Discussion: According to a poll in 2016, There were $80 \%$ of Taiwaness said that they're happy with the national health insurance system. Those numbers reflect well on the high quality of healthcare in Taiwan. The life expectancy in Taiwan has better infant mortality rate [1].

Result: What is remarkable is that the Taiwan's national health insurance system is cheap compared to that of the United States. Taiwan spends 6 percent of its GDP on healthcare, compared with the US' 15.3 percent. 1 Experts say that the key to Taiwan's more efficient nursing care and health care systems seems to be the combination of a single-payer system with world-beating healthcare technology.

Taiwan launched its single-payer system in 1995. Nine years later, a "smart card" was introduced. Each of Taiwan's 23 million people has a card with basic identification and medical data on it. When a Taiwanese patient goes to a clinic or hospital, a swipe of the card immediately gives the doctor instant access to all that data. And information on the visit is uploaded to a central database that gives the government a near "real time" lucid picture of healthcare patterns [2]. The effective use of information technology as well keeps administrative costs so low that it is now 1.5 percent of total medical expenditures and is probably the lowest cost in the world. Undeniablly, there is some buzz about the digital future of U.S. nursing care and healthcare and then are centered on the electronic health records.

The biggest advancement might be the small card we can carry with us. The plastic credit card carries all the essentials data of nursing and health cares: medical records, insurance information, prescriptions, and also reimbursements. It not only can be used to check in, but also if it's used quite effectively, can easily identify both the patients, and providers with a complete background data on the patients whenever they visiting. The United States is a global superpower and the most innovative country in this world. Yet it has not entered the smart-card market largely because of its fragmented health-care system. We do have thousands of private hospitals and insurers and no single government agency to act as the issuer. The overview of the smart card and network technology; privacy and security requirements are to be noted. As to benefits of using IC cards are quite obvious [3]. Any disadvantages of using them may be due to privacy concerns. As per Denish D'Souza in his book 4, p.19, Russia is one of the most atheist countries in the world, and abortions there outnumber live births by a ratio of two to one. Russia's birth rate has fallen so low that the entire nation is now losing 700,000 people a year.

Japan, perhaps the most secular country in Asia, is also on a kind of population decline: its 130 million people are expected to drop to around 100 million in the next few decades. 
Canada, Australia, and New Zealand find themselves in a similar predicament. Then there is Europe. The most secular continent on this globe is decadent in the quite literal sense that its population is rapidly shrinking. Well, Nietzsches "last man" is finally here, and his name is Sven! Nevertheless, most this author's Christiam pals feel that 'do not worry!' This world is already overpopulated This author does not deem Christianity promote more birth rate. Apostle Paul used to advise if for widows, then, as it is said in the BIBLE New Testament, in the 1 Chorinthine 7:1 preferring not to get re-married. That is why Catholic has priests and nuns. The high abortion rate in Russia, if that is true, may reflect low availability of contraceptives. The Caucasian people already colonized Siberia. Americas and Australia. China, if not for the one child- policy, would still be a poor country [4]. Meanwhile the non-Christian countries in South Asia, Mideast and Africa have population explosion and sending most "refugees" everywhere else!.

\section{Conclusion}

How can IC card helps patients, hospitals, and providers? What is 'Don't worry'? This world is already overpopulated. I don' think Christianity promote babies. Paul advised not to get married. That is why Catholic has priests and nuns. The high abortion rate in Russia, if that is true, may reflect low availability of ant effective contraceptives. The Caucasians already colonized Siberia. Americas and Australia. China, if not for the one child policy, would still be a poor country. Meanwhile the non-Christian countries in South Asia, Mideast and Africa have population explosion and sending "refugees" everywhere. Conversely, will any change in the government's health policy push the hospitals and providers toward the direction of smart card technology?

\section{References}

1. Jonathan Adams (2018) In Taiwan, your medical file on a card.

2. Bing Tang (1998) The need of IC cards for the National Health Insurance in Taiwan.

3. Bing Tang (2009) Quality analysis on the communication among science/Technology 1(1).

4. Denish D Souza (2007) What's So Great about Christianity, 2007 Tyndale House Inc. Illinois.

Your next submission with Juniper Publishers
will reach you the below assets
- Quality Editorial service
- Swift Peer Review
- Reprints availability
- E-prints Service
- Manuscript Podcast for convenient understanding
- Global attainment for your research
- Manuscript accessibility in different formats
( Pdf, E-pub, Full Text, Audio)
- Unceasing customer service
Track the below URL for one-step submission
https://juniperpublishers.com/online-submission.php

